NBER WORKING PAPER SERIES

\title{
AN ANALYSIS OF THE EARNINGS OF CANADIAN IMMIGRANTS
}

David E. Bloom

Morley Gunderson

Working Paper No. 3035

NATIONAL BUREAU OF ECONOMIC RESEARCH

1050 Massachusetts Avenue

Cambridge, MA 02138

July 1989

An earlier version of this paper was presented at the NBER Conference on Trade, Immigration, and Labor in September 1987. The authors are indebted to McKinley Blackburn, Anne Hill, Robert Kornfeld, David Neumark, Andrew Newman, and Marcus Rebick for assistance in the preparation of this paper and to Blackburn, Rebick, Richard Freeman, Mark Killingsworth, Jacob Mincer, and Glenn withers for helpful discussions and comments. This research was supported by NIH Grant No. HD18844-02 and by a grant from the Ford Foundation to the National Bureau of Economic Research. This paper is part of NBER's research program in Labor Studies. Any opinions expressed are those of the authors not those of the National Bureau of Economic Research. 
NBER Working Paper \#3035

July 1989

AN ANALYSIS OF THE EARNINGS OF CANADIAN IMMIGRANTS

ABSTRACT

This paper reports estimates of simple wage equations fit to cross-sectional and pseudo-longitudinal data for Canadian immigrants in the 1971 and 1981 Canadian censuses. The estimates are used to assess (1) the usefulness of crosssectional analyses for measuring the pace of immigrant earnings growth, (2) the labor market implications of admissions policies that place different weights on the work skills possessed by prospective entrants, and (3) the relative impact of selective outmigration and job-matching on the shape of immigrant earnings distributions as duration of stay increases.

The estimates provide evidence of a small to moderate assimilation effect that suggests that immigrants make up for relatively low entry wages, although the wage catch-up is not complete until 13 to 22 years after entry into Canada. These results are revealed clearly in both the pseudo-longitudinal and the cross-sectional analyses. The estimates also provide evidence that the unobserved quality of immigrants' labor market skills declined following changes in Canada's immigration policies in 1974 that led to a sharp increase in the proportion of immigrants admitted on the basis of family ties. Finally, since there is no evidence that the variance of immigrant earnings increases with their duration of stay in Canada, and since there are no differential immigrant-native changes in higher-order moments of the earnings distribution as duration of stay increases, the results are inconclusive with respect to the importance of selective outmigration and job matching in the evolution of immigrant earnings distributions over time.

David E. Bloom

Department of Economics

Columbia University

New York, NY 10027

(212) 854-8758
Morley Gunderson

Department of Economics

Centre for Industrial Relations

University of Toronto

Toronto M5S $1 \mathrm{Al}$

(416) 978 - 5398 
The purpose of this paper is to analyze immigrant labor market progress In Canada - a country that has screened most of its immigrants on the basis of their expected "ability to assimilate" as a matter of official policy. In particular, we compare earnings profiles for Canadian immigrants and natives and seek to determine whether immigrant earnings profiles reflect any "vintage effects" associated with year of immigration.

Over the past 10 years, a number of studies of immigrant earnings have focused on these same issues using data for U.S. immigrants. Among the best known is that by Chiswick (1978) which fits a standard wage equation to cross-sectional data on immigrants and natives in the 1970 Public Use Sample of the U.S. Census. Chiswick's results support the conclusion that, when they first enter the labor market, immigrants earn approximately 25 percent less than natives with comparable years of schooling and experience, marital status, etc. However, Chiswick also finds that immigrants have steeper experience-earnings profiles than "comparable" natives, with immigrant earnings overtaking native earnings within roughly 13 years of their entry into the U.S. A number of other studies have fit the same basic model to similar data and have reached roughly identical conclusions (see, for example, Carliner, 1980; Long, 1980; and Borjas, 1982).

The set of findings based on Chiswick's approach to measuring immigrant assimilation has been challenged by Borfas (1985) who argues that the steepness of immigrant earnings profiles is inflated by cross-cohort declines in immigrant quality. Evidence supporting this argument is provided by using pooled data from the 1970 and 1980 U.S. Population Censuses to measure earnings growth in the intercensal period for individual entry cohorts of immigrants. Based on this analysis, Borjas concludes that 
"cross-section studies of immigrant earnings provide useless and misleading insights into the process of immigrant assimilation into the labor market" (p. 485).

Borjas' conclusion is deserving of further examination. A priori theoretical reasoning is perhaps more consistent with Chiswick's empirical conclusions than they are with those of Borjas. Low entry wages for immigrants can plausibly be explained as a loss of (origin) country-specific human capital; rapid earnings growth can be viewed as reflecting positive self-selection into immigration (i.e., immigrants are above-average in terms of their aggressiveness, ambitiousness, willingness-to-work hard, etc.). In contrast, sizable cross-cohort declines in immigrant quality are somewhat harder to accept given that it is not overall quality that is hypothesized to have declined, but rather that component of overall quality that is unmeasured (i.e., the part of immigrant quality that is not measured by or correlated with variables such as schooling, experience, marital status, country of origin, etc.). Borjas' results, as he recognizes, may also be reflective of differential patterns of underenumeration in the successive censuses, or non-random intercensal mortality and outmigration. Indeed, outinigration, death, or undercounting of immigrants who are relatively unsuccessful in the labor market are all alternatives to declining immigrant quality as an explanation of Chiswick's cross-sectional results.

We will also use the example of Canada as an opportunity to gain some insight into the importance of intercensal exiting from an immigrant population. Although there is little information on either the covariates of immigrant mortality or on differential census undercounting of immigrants, there are several established lines of inquiry on the subject of outmigration. According to a group of imperfect information models, outmigration is an event that was unplanned ex ante and that occurs 
primarily among migrants whose labor market expectations are not satisfied (see Yezer and Thurston, 1976; Allen, 1979; Blejer and Goldberg, 1980; and Lam, 1986). These models suggest, at the margin, that outmigrants will tend to be selected from the lower end of the earnings distribution. On the other hand, intertemporal substitution models tend to view outmigration as a planned event among individuals who make short-term moves in order to take maximal advantage of temporarily favorable earnings opportunities (Stark and Bloom, 1986; Fox, 1987). These models suggest that outmigration will be most prevalent among individuals who are relatively active and successful in the labor market. Although the results are far from definitive, empirical research by Jasso and Rosenzweig (1987, 1989) and by Lam (1987) tends to support this view insofar as outmigration of U.S. and Canadian immigrants is reported to be most prevalent among those who are relatively successful.

Although they are extremely different in spirit, both the imperfect information and the intertemporal substitution models of outmigration share an important empirical implication, namely, that the variance of residuals in a migrant earnings equation will decline with duration of stay (1.e., under the imperfect information models exit occurs at the lower end of the distribution while under the intertemporal substitution models exit occurs at the upper end). In contrast, job matching or asymetric information models imply that the residual variance in a wage equation will increase with duration of stay as employers are increasingly able to observe the true productivity of migrants (see Harris and Holmstrom, 1982; Katz and Stark, 1984). We attempt to infer which set of forces tends to be stronger by examining patterns in the variance and kurtosis of immigrant earnings by duration of stay. For example, we will interpret an increase (decrease) in the variance of earnings with duration of stay as evidence favoring the 
relative importance of the job matching models (imperfect information mode1s).

Thus, we have four main goals in this paper. First, by fitting the models proposed by both Chiswick and Borjas to data for Canada, we hope to assess the extent to which it is generally true that cross-sectional studies of immigrant earnings are "useless and misleading." Second, we hope that estimates of these alternative models will lead to clear substantive conclusions regarding the shape of immigrant earnings profiles and the importance of entry-cohort effects on earnings. Third, by comparing corresponding results under different Canadian immigration policies, we hope to shed some light on the significance of a nation's institutions in determining the economic benefits of immigration. Finally, by analyzing the variance of immigrant earnings by duration of stay in Canada, we hope to assess the relative importance of selective intercensal exiting and jobmatching/asymmetric information in models of the labor market progress of immigrants.

\section{Immigration Policy and Immigrants in Canada}

In an effort to enrich our interpretation of statistics related to the labor market experience of Canadian immigrants, this section will present a brief review of the history of Canadian immigration policy and of immigration to Canada.

\section{A. Brief History of Canadian Immigration Policy}

From the 19 th to the 20 th century, international migration to developed countries has been determined less and less by events and decisions of individuals in countries of origin and more and more by regulations established in countries of destination. In this regard, Canada is no 
exception. Until 1869, Canada's immigration policy was simply one of free entry. But beginning that year, a series of legislative enactments established specific principles of selection and associated regulatory apparatuses. Prohibitions were established on the landing of "criminals and other vicious classes" in 1872, paupers and destitute immigrants in 1879, and diseased persons in 1902 . In 1904 an exorbitant head tax of $\$ 50$ (Canadian) was established for Chinese immigrants. During this period of years, the central government also set up quarantine stations, specified legal responsibilities for companies involved in transporting immigrants, and began to require those companies to make deposits into a fund whose purpose was to cover the expenses of indigent immigrants before they were able to secure employment.

The basic structure of Canadian immigration policy during much of the first half of the 20th century was set forth in the Immigration Act of 1910 . This Act firmly established the principle of selective immigration by creating a proscribed class of immigrants: those ndeemed undesirable because of climatic, industrial, social, educational, labour, or other conditions or requirements of Canada, or deemed undesirable because of their customs, habits, modes of life and methods of holding property and their probable ability to become readily assimilated." In practical terms, this Act led to a distinction between countries in the extent to which they were considered to be "preferred" or "non-preferred." The two most preferred countries were the United Kingdom and the United States (and France as of 1947); they were followed by several other countries in northern and western Europe that were "not too different [from Canada] in language and mode of life;" countries in central and eastern Europe were considered to be nonpreferred, with the most non-preferred countries being Greece, Italy, Syria, and Turkey. Immigrants from Asian countries were considered so undesirable 
that their admission was strictly regulated under separate Acts.

Subject to time-varying restrictions on total immigrant volume, applicants from the most preferred countries were admitted on almost a laissez-faire basis while the admission of immigrants from other preferred countries depended to varying degrees on whether they possessed training and skills for which there was a need in Canada. Only immigrants in a relatively narrow range of occupations (e.g., agriculture) were admissible from non-preferred countries, and the range of relatives they could bring with them was quite limited.

One of the chief characteristics of twentieth century immigration policy in Canada is its strong labor market orientation. In a broad statement outlining the principles that have guided Canadian immigration policy throughout the post-World War II era, Prime Minister Mackenzie King declared in 1947 that Canada would encourage immigration to meet its need for population. He said further that Canada would accept as many immigrants "as could be advantageously absorbed into the national economy," with the admissibility of potential immigrants to Canada depending upon, among other factors, labor conditions and requirements in Canada and each applicant's "ability to assimilate." King also affirmed the discriminatory features of Canada's immigration policy, stating that "the people of Canada do not wish, as a result of mass immigration, to make a fundamental alteration in the character of our population." "Canada is perfectly within her rights in selecting the persons whom we regard as desirable future citizens. It is not a 'fundamental human right' of any alien to enter Canada. It is a privilege. It is a matter of domestic policy..."

Because control over the volume of immigrants to Canada and over their national and occupational composition resided in the hands of the Cabinet, 
immigration policy in Canada has been remarkably responsive to a variety of social, economic, and political situations throughout most of this century. For example, immigration was tightly restricted during the high unemployment years of the 1930's, immigrants were not accepted from Japan, Germany, or Italy during World War II al though many displaced Europeans were admitted from other countries, and Canada actively assisted and accepted many immigrants from Hungary during 1957.

Canadian immigration policy has often been referred to as a "tap-on, tap-off policy" because of its flexibility and its responsiveness to contemporary labor market concerns. For example, the admission of immigrants was increased sharply as a response to labor shortages in the 1950 's, but was curtailed during the years 1958-1962 due to high rates of unemployment. Beginning in the 1950's, immigration officials treated professionals and entrepreneurs with capital quite favorably because of their potential to generate employment opportunities in Canada. Indeed, Canada abandoned its policy of national discrimination in the 1960's partly because it became increasingly clear that Canada would not be able to satisfy its need for skilled manpower via immigration from its list of preferred countries.

In 1967, Canada substantially altered the mechanisms by which it administered its immigration policies. First, it eliminated all discrimination on the basis of race or nationality. Second, it defined four classes of immigrant applications: (1) sponsored relatives (1.e., dependent relatives); (2) nominated relatives; (3) independent applications; and (4) refugees. Sponsored relatives would be admissible merely if they could demonstrate that they were in good health and of good character. Refugees, a status defined by the United Nations, would be accorded preferential treatment in admission. Finally, nominated relatives and independent 
applications would be judged on the basis of a point system.

The two key features of the point system are that it removed a good deal of subjective authority from the hands of immigration officers and it assigned considerable weight in admissions decisions to labor-market related factors. In order to be admitted under the point system, an immigrant needed to receive at least 50 points out of a maximum of 100 . Points were awarded according to the following 9 criteria, with some minor differences in the evaluation of independent applications and applications from nominated relatives:

(1) Education and training: 1 point for each year of successful formal education or occupational training, up to a maximum of 20 ;

(2) Personal characteristics: Up to 15 points awarded at the discretion of immigration officers on the basis of their perception of the applicant's adaptability, resourcefulness, initiative, and motivation;

(3) Occupational demand: up to 15 points, both for skilled and unskilled workers;

(4) Occupational skill: ranging from 1 point for unskilled workers up to 10 points for professionals;

(5) Age: 10 points for applicants below the age of 35 , with 1 point less for each year above age 35 (with a minimum of 0 points);

(6) Arranged employment: 10 points for applicants with a definite job in Canada;

(7) Knowledge of French and English: Up to 10 points depending on an applicant's fluency in French and English;

(8) Relatives: up to 5 points for applicants with relatives in Canada that could help them to get established;

(9) Employment opportunities: up to 5 points for applicants moving to areas of strong labor demand.

The point system was amended in 1974, as a response to both the large number of immigrants admitted to Canada in 1972 and 1973 and to increases in the unemployment rate in Canada. A priority system was established for 
processing immigrant applications that gave preferential treatment to applicants with close relatives in Canada, applicants with prearranged employment in high-demand occupations, and to entrepreneurs and refugees. A "Canadians-first" policy was also established under which applicants would receive no credit for prearranged employment unless they could show that no equally-qualified Canadian citizen or landed immigrant was available to fill the position. In addition, an applicant would lose 10 points if there was no evidence of pre-arranged employment or bona fide demand for their labor. The figures in Table 1 indicate that a sharp increase occurred in the proportion of Canadian immigrants admitted on the basis of family ties following the 1974 policy changes.

\section{B. Trends and Patterns in Immigration to Canada}

The foreign-born have constituted a sizable fraction of the Canadian population throughout the twentieth century. In $1901,13.3$ percent of the Canadian population was foreign-born. This fraction increased sharply during the first decade of the century and hovered around 22 percent into the 1930's, when difficult economic circumstances led to restrictive immigration policies that caused it to decline. Nonetheless, the foreignborn fraction of the Canadian population had not fallen below 15 percent through the early 1980's (see Table 2).

In order to maintain such a high fraction of foreign-born among the Canadian population, Immigration flows into Canada have been quite substantial. For example, there were 4.4 million immigrants to Canada from 1951 to 1981 , a perlod during which the population of Canada increased from 14 to 24 million. Although the ratio of new immigrants to the overall increase in the size of Canada's population has been above 15 percent during every year in the post-World War II era, there has been a great deal of 
year-to-year variation in the number of immigrants. Especially large numbers of immigrants arrived in Canada in $1951(194,391), 1957(282,164)$, $1967(222,876)$ and $1974(218,465)$; in contrast, relatively few immigrants arrived in 1946-47 (roughly 68,000 immigrants per year), 1961-62 (roughly 73,000 immigrants per year), $1978(86,300)$, and $1983(88,800)$.

From the mid-1950's to the mid-1970's, the percent of Canadian immigrants intending to enter the labor force was just above 50 percent. That figure dropped to 44 percent starting in the mid-1970s, as the number of admissions from independent applications dropped from nearly 110,000 in 1974 to under 21,000 in 1984. Even more dramatic has been the shift in the distribution of occupations among immigrants expecting to enter the labor force. This shift has been notably in the direction of increased skill and training. Among immigrants entering Canada during 1954-58, only 12 percent listed their intended occupations as managers or professionals. In contrast, 37 percent listed agricultural worker, laborer, or service worker as their intended occupation. During the years 1979-83, the percent of managers and professionals increased to 28 percent while only 14 percent of immigrants reported that they intended to work as agricultural workers, laborers, or service workers. While some portion of these changes undoubtedly reflect sectoral shift in the Canadian economy, the bulk of the changes are reflective of the increased emphasis on skill and training in Canada's immigration policy (see Table 3).

Table 4 presents a crosstabulation of the foreign-born population of Canada by their country of origin and their year of immigration. The data are taken from the 1981 Canadian Census. The figures clearly show that British and American immigrants dominated the immigration flow to Canada before 1946 (i.e., in 1981, 61 percent of all pre-1946 immigrants in Canada were from the U.K. or the U.S.). That dominance ended immediately following 
World War II as Immigration from Europe (excluding the U.K.) expanded sharply. From 1946 to 1955,68 percent of all immigrants to Canada were from Europe (excluding the U.K.), up from just 37 percent prior to 1946 . Germany, Italy, and the Netherlands alone supplied an especially large proportion of immigrants in the ten years following the war (36 percent). Even in absolute terms, no European country increased the number of immigrants it supplied to Canada during the post-War period, whereas the number of immigrants from most European countries actually declined (i.e., based on numbers of immigrants actually in Canada in 1981).

Table 4 also shows that the pattern of immigration to Canada changed rather dramatically when Canada stopped discriminating among immigrants on the basis of their countries of origin. For example, between the first and second half of the $1960^{\prime} s$, immigration to Canada from Asia and Latin America increased nearly four-fold. Although these regions of the world supplied only 2 percent of Canada's immigrants prior to 1946, they supplied 46 percent from 1971 to 1975 and 55 percent from 1976 to 1981 .

\section{Immigrants in the Canadian Labor Market}

We next present a brief descriptive analysis of the employment, unemployment, and earnings experience of male immigrants represented in the 1971 and 1981 Canadian population censuses.

Table 5 reports selected labor market characteristics of immigrants and natives based on data contained in the 1981 Canadian Census of Population. Judging merely, on the basis of labor market activity measures, it would not be unreasonable to conclude that Canadian immigrants are well assimilated in the labor market. The labor force participation rate of male immigrants (aged 15 and over) was 72.4 percent in 1981, just slightly below the rate of 73.6 percent for native Canadians. The closeness of native and immigrant 
labor supply extends beyond labor force participation rates to hours and weeks worked as well. Ninety-three percent of immigrant males worked 35 or more hours during the 1981 Census reference week, compared to 92 percent of native males. Similarly, 70.6 percent of the male immigrants reported having worked 49 to 52 weeks in 1980 , just .2 percentage points higher than the figure for native males. Despite the closeness in these measures of immigrant and native labor supply, unemployment rates for immigrants were notably lower than for natives in 1981 (i.e., among males, the unemployment rates were 8.5 percent for natives and 5.3 percent for immigrants). These differentials could reflect a variety of factors including differences in reservation wages, human capital, and demographic composition (see Fox, 1987 for an analysis of immigrant labor supply and unemployment in Canada). Presumably, such factors also underlie the explanation of the difference in average income between male immigrants and natives (i.e., the immigrants had a 7.4 percent advantage). It is also worth noting that rates of selfemployment are slightly higher among immigrants than among natives, with 15 percent of immigrant males reporting that they were self-employed in 1981 (compared to 13 percent for native males).

Table 6 compares labor force participation rates, unemployment rates, and levels of average income among different entry cohorts of Canadian immigrants -- using data from both the 1971 and 1981 Canadian censuses. The statistics show that the more recent immigrants have relatively low labor force participation rates, relatively low average income, and relatively high unemployment rates. Labor force participation rates are also relatively low in both censuses for pre-1946 immigrants, presumably because many immigrants in that cohort had reached retirement age by 1971 and 1981 . Although labor force participation rates are quite flat across the cohorts 
of immigrants that entered Canada between 1946 and 1975 , it does appear that unemployment rates are higher for the more recent cohorts. Average immigrant earnings also tend to be lower for immigrants in the more recent entry cohorts.

Thus, while there do not seem to be major differences in the employment and earnings experiences of immigrants and natives in Canada, there are notable differences between immigrants in different entry cohorts. Whether these differences represent genuine vintage effects or simply reflect the influence of immigrant labor market characteristics or other variables cannot be determined from these tables. Making such a determination requires that we control for a variety of variables in a multivariate manner, which we turn to in the following section.

\section{Empirical Analysis of Immigrant Earnings Profiles}

In this section, we will analyze earnings patterns among Canadian imigrants using data contained in the 1971 and 1981 Canadian censuses. Our goal is to answer the following three questions:

(1) On average, do employed immigrants receive higher wages than employed natives who are comparable in terms of observed productivityrelated characteristics?

(2) On average, do employed immigrants who have been in Canada for a total of $\mathrm{X}$ years receive higher or lower wages than employed immigrants who have been in Canada for $X+Y$ years but who are otherwise comparable in terms of observed characteristics? and

(3) Does the dispersion of immigrant earnings tend to vary with duration of stay? 


\section{A. Empirical Models and Data Issues}

The standard model used to compare earnings profiles for immigrants and natives was proposed by Chiswick (1978). The basic regression model, which is fit to cross-sectional data for a pooled sample of both immigrants and natives, is a simple extension of the standard human capital earnings function:

$$
\log Y=a_{0}+a_{1}(S C H)+a_{2}(E X P)+a_{3}(E X P S Q)+a_{4}(I M M I G)+a_{5}(Y S M)
$$

where $\mathrm{Y}$ is earnings, $\mathrm{SCH}$ is years of schooling, EXP is years of labor market experience, EXPSQ is years of labor market experience squared, IMMIG is an indicator variable for immigrants, and YSM is years since migration interacted with the immigrant dumny variable. The estimate of $a_{4}$ measures the average percent difference between the earnings of natives and newly arrived, but otherwise comparable, immigrants. The estimate of $a_{5}$ measures the average percent increase in immigrant earnings with each year they spend in their new home country, beyond the increase in earnings associated with the fact that their human capital stock may have changed during that year (e.g., EXP may have increased). Thus, a positive estimate of $a_{5}$ has been taken to indicate that the average experience-earnings profile of immigrants is steeper than that of natives, which is suggestive of labor market progress and assimilation.

Borjas (1985) has recently pointed out that interpreting the coefficients in equation (1) in this manner requires one to assume that there are no omitted variables that are correlated with YSM. This assumption may be difficult to defend because YSM also measures "date of entry into the new country" in a cross-sectional regression. If unmeasured factors relevant to labor market success vary systematically across entry cohorts of immigrants, the coefficient $a_{5}$ will measure both immigrant labor 
market progress and the effect of the average difference in unmeasured factors across successive entry cohorts (i.e., it may be a biased measure of the labor market progress experienced by different entry cohorts over time).

The most straightforward way to overcome the fact that YSM is a linear combination of a vector of year-of-immigration dummy variables in crosssectional data is to make use of longitudinal data. Since longitudinal data provide observations on each entry cohort at two or more points in time, it is possible to estimate the effect of time spent in the new country on earnings without the potentially confounding influence of entry cohort effects (i.e., a regression model can be specifled with year-of-immigration dummy variables and YSM on the right-hand side because the same individual in a particular entry cohort, with an immutable "year of entry," will have different values of YSM when he is observed at different points in time).

To our knowledge there are no sets of longitudinal data for Canada that are suitable for conducting such an analysis. Thus, following Borjas, we will construct a pseudo-longitudinal dataset for different entry cohorts of immigrants using data contained in the 1971 and 1981 Canadian Population Censuses. We will fit the following regression model to pooled data from these two censuses:

$$
\begin{aligned}
\log Y=b_{0} & +b_{1}(S C H)+b_{2}(\text { EXP })+b_{3}(\text { EXPSQ })+b_{4}(\text { IMMIG })+b_{5}(\text { YSM }) \\
& +c_{1}\left(\mathrm{COH}_{1}\right)+\ldots+c_{k}\left(\mathrm{COH}_{k}\right)
\end{aligned}
$$

where $\mathrm{COH}_{1}$ through $\mathrm{COH}_{k}$ are indicator variables reflecting immigrant membership in different entry cohorts. In principle, fitting this regression provides estimates of cohort-specific effects on earnings as well as an estimate of the average rate of earnings growth that is free of entrycohort bias (i.e., an estimate of earnings growth within -- and not across - 


\section{- entry cohorts).}

Several features of this econometric approach should be kept in mind. First, it cannot be used to estimate individual-specific effects on earnings because there is no information to link the same individuals in the different cross-sections. Second, a particular entry cohort sample observed in 1971 is not necessarily representative of the same population as the corresponding sample that is observed in 1981. As noted earlier, non-random patterns of outmigration, mortality, and differential undercounting - of which we find some evidence in our data as well as in Lam (1987) -- will tend to undermine the comparability of the samples. Changing patterns of employment and self-employment pose similar problems insofar as our regressions are fit to samples of working individuals who earned their income primarily from wages and salaries. Third, because only two crosssections are available for the present analysis, we will not be able to control for period effects that may affect the earnings of different cohorts differently (e.g., the business cycle).

Also deserving of mention are two issues rasied by the pooling of data from two cross-sectional samples. First, in order to meaningfully compare earnings in the 1971 and 1981 censuses, it is necessary to make an adjustment for inflation. We do this by using the Canadian Consumer Price Index to transform earnings in the 1971 census (that refer to the year 1970) into 1980 inflation-adjusted dollars (the multiplication factor is 2.17). Second, intercensal changes in the real earnings of immigrants may be partly due to changing capital-to-labor ratios, technological change, or business cycle fluctuations. Since real wage growth due to these factors is not reflective of labor market progress that is immigrant-specific, we make an adjustment to the real earnings of immigrants in the 1971 census that transforms those data into "productivity-constant" terms. These adjustments 
highlight our central interest in this section: measuring the component of intercensal earnings growth for different entry cohorts of immigrants that is independent of human capital accumulation, overall economic growth, business cycle effects, inflation, etc.

In order to explore the robustness of our results, we make two distinctly different types of productivity adjustments. First, we simply multiply immigrant earnings reported in the 1971 census by the ratio of real earnings recelved by native Canadians in the 1981 and 1971 censuses (the multiplication factor is 1.20). This simple adjustment assumes that immigrants would have experienced the same real wage growth as natives in the absence of any assimilation effects. At a somewhat deeper level, it assumes that average levels of human capital did not change among natives relative to immigrants and that the structure of returns to different types of human capital also did not change between censuses. To avoid these assumptions, we also employ a slightly more complex productivity adjustment that takes account of changes in the human capital profile of the immigrant and native labor forces and of changes in the returns to different types of human capital. We do this by (a) estimating real wage equations for natives in 1971 and 1981 and (b) using the difference in the estimated coefficients to adjust immigrants' 1971 wages for intercensal changes in the returns to different types of human capital. We report results based on both sets of adjustments below.

\section{B. Empirical Results on the Level of Earnings}

The immigrants we analyze represent 1-in-100 samples of individuals born outside of Canada while the natives represent $1-i n-600$ samples of individuals reporting Canada as their place of birth. Both the immigrant and native samples are restricted to individuals aged 20-64 who are not 
predominantly self-employed and who worked at some point during the year prior to the census for a wage in excess of 50 cents per hour in the 1971 census and one dollar per hour in the 1981 census. The variables IMM4650 through IMM7680 refer to immigrant entry cohorts (e.g., year of entry from 1946 to 1950 , etc.).

Table 8 presents ordinary-least-squares estimates of wage equations using cross-sectional data from 1971 and 1981 separately. The dependent variable in all equations is the natural logarithm of an individual's wage and salary earnings in inflation-adjusted (1980) dollars during the year preceding the census (i.e., 1970 and 1980). These equations were specified with schooling (SCH), experience (EXP and EXPSQ), marital status (MST), and vectors of categorical variables (not reported in the table) measuring hours worked per week and weeks worked per year as right-hand-side variables. Depending on the specification, the wage equations may also include an indicator variable for immigrants (IMMIG) and a variable measuring the number of years an immigrant has been in Canada (YSM). Al though not. reported in these tables, we also estimaced models with additional right. hand-side variables reflecting an individual's religion and language ability and the square of YSM. Since these latter variables had little explanatory power either individually or jointly, these specifications are not reported here in the interest of parsimony.

The first two columns of Table 8 report wage equation estimates for the samples of male immigrants in 1971 and 1981. The estimated equations have the basic structure one might expect: a 4 to 5 percent rate of return to schooling, an earnings-experience profile that increases at a decreasing rate, and a 15 to 25 percent positive wage differential for married men. In addition, the "years since migration" coefficients are positive and 
significantly different from zero, although the coefficients are rather small in magnitude (i.e., about .5 percent per year).

The third and fourth columns of Table 8 report estimates of similar equations for native Canadians. The pattern of results corresponds quite closely to those for the immigrants, although the rate of return to schooling is slightly higher for natives than for immigrants, probably indicating that schooling has an important country-specific component. Even the residual variances for the immigrant and native wage equations are quite close in magnitude (e.g., .20 for the immigrants and .21 for the natives in the 1971 census data).

Given the closeness of the estimated wage equations for the immigrants and the natives, a simple way to compare the wage profiles is to follow the work of Chiswick (1978) by pooling the data for the two groups and fitting a wage equation that includes a dummy variable for immigrants, both by itself and interacted with the "years since migration" variable. The results of this exercise are presented in the last two columns of Table 8 . Based on the 1971 data, the estimate of the immigrant coefficient indicates that immigrants earn roughly 7 percent less than comparable natives when they first arrive in Canada; the estimate of the coefficient on YSM indicates that immigrants' wages increase an average of .54 percent per year spent in Canada, beyond the increase associated with the acquisition of experience. These estimates imply that the earnings profiles of comparable immigrants and natives cross at roughly 12.8 years. In contrast, the 1981 data indicate that entering immigrants earn 16.6 percent less than otherwise comparable natives, although their wages increase at the rate of .77 percent per year spent in Canada suggesting that the immigrant and native earnings profiles do not cross until the immigrants have been in Canada for 21.6 years. 
In order to investigate whether the various cross-sectional estimates of immigrant labor market progress are biased by entry-cohort effects on wages, we now estimate alternative models from pooled 1971 and 1981 data on immigrants. The first column of results in Table 9 reports estimates of the simple wage equation fit to the pooled data. As one would expect, these estimates are quite similar to the estimates computed for the separate years' samples (i.e., they are simply a matrix-weighted average of the results in columns 1 and 2 of Table 8). In the second column, we include a vector of dummy variables that reflect an immigrant's entry cohort. The coefficient of YSM in this equation therefore represents a weighted average of within-cohort real earnings growth between 1971 and 1981 for the different entry cohorts, other things equal. The estimate of this coefficient is quite substantial in magnitude ( 2.02 percent) and is quite well-determined (i.e., the standard error is .08 percent). Thus, the within-cohort growth rate of real earnings is three to five times larger than the cross-cohort growth rate of real earnings. In addition, estimates of the cohort fixed effects suggest that the average unmeasured quality of immigrants increased across all entry cohorts until the cohort that entered from 1976 to 1980 .

As noted earlier, the coefficient on YSM captures both the true "assimilation effect" in which we are interested, as well any wage growth associated with changes taking place in the economy over time (e.g., increasing capital-to-labor ratios). In order to isolate the assimilation effect, we adjust the 1971 earnings data for changes in labor productivity that occurred among native Canadians from 1971 to 1981. Estimates of the wage equation fit to these productivity-adjusted data are reported in the third and fourth columns of Table 9. The third column applies the simple 
adjustment described above based on the ratio of real wages received by native Canadians in 1971 and 1981; the fourth column applies the more complex regression-based adjustment that accounts for human capital changes among the immigrant and native labor forces as well as changes in the returns to different types of human capital.

The coefficient of YSM reported in column 3 is .24 (with a standard error of .08). Although it is statistically significant, this estimate is substantially smaller than the estimate of 2.02 computed using nonproductivity-adjusted data. Thus, it appears that the effect of assimilation on the earnings of pseudo-cohorts of immigrants is quite sma11, indeed, almost negligible. Put another way, within-cohort growth in immigrant earnings is primarily due to economic forces that affect both immigrants and natives. Further confirmation of this result is provided in the fourth column of Table 9. Although the estimated coefficient of YSM is somewhat larger when we apply the more elaborate productivity adjustment, the assimilation effect of .42 percent per year is still substantively sma11. Moreover, it is sufficiently close in magnitude to the estimates computed from the individual cross-sections to justify taking issue with Borjas' assertion that estimates of the latter type are "misleading and useless."

It is also worth examining the estimates of the cohort fixed effects in columns 3 and 4 in Table 9 . There are no statistically significant cohort effects among any of the five pre-1971 entry cohorts of immigrants. However, the estimates do suggest that average unobserved quality among immigrants arriving from 1976 to 1980 (and perhaps also among the 1971 to 1975 arrivals) was significantly lower than for previous cohorts, the same conclusion suggested by a comparison of the cross-sectional coefficient estimates of IMMIG in Table 8 . This result is not especially surprising 
given the relatively high fraction of immigrants admitted into Canada as relatives of Canadian citizens and landed immigrants in the late 1970's (see Table 1). Under the immigration policy in effect in Canada in the 1970's, applications from relatives did not receive the same degree of labor market screening as independent applications.

\section{The Dispersion of Immigrant Earnings}

In this subsection we present and review statistics on the dispersion of income among immigrants. In particular, we are interested in determining whether immigrant incomes tend to become more or less disperse as the duration of their stay in Canada increases. A tendency for dispersion to decline with duration of stay is consistent with the hypothesis that intercensal outmigrants tend to be selected from the tails of the distribution (i.e., immigrants whose earnings expectations were not met selected out of the lower tail while migrants who planned temporary stays to take advantage of favorable earnings opportunities selected out of the upper tai1). In contrast, a tendency for dispersion to increase with duration of stay would be consistent with the view that the labor market has more information about the true productivity of immigrants the longer they have stayed in the country.

The third and fourth columns of Table 10 report the raw standard deviations of immigrant incomes by the duration of their stay in Canada as of both 1971 and 1981. Although the standard deviation of income is highest for the oldest entry cohort of immigrants, there is little evidence of a pattern across the more recent entry cohorts in either census year. There is some tendency for income dispersion to decrease for individual entry cohorts from 1971 to 1981 , but this may not be due to increased duration of stay since income dispersion among native Canadians also decreased between 
1971 and 1981. In addition, it is worth noting that the standard deviation of immigrant incomes is remarkably close to the standard deviation of native incomes in both census years. Table 10 also reports the standard deviation of the estimated residuals for different entry cohorts of immigrants in the 1971 and 1981 censuses. These statistics are more appropriate measures of dispersion than the raw standard deviations because they do not reflect the influence of variations in observable factors that are associated with earnings. Nonetheless, they tell basically the identical story to that told by the unconditional measures of dispersion: there is no substantial evidence of a difference between natives and immigrants, or among immigrants with different durations of stay in Canada, in the dispersion of income. Thus, the statistics in Table 10 are equally supportive of two conclusions: first, that selective outmigration and job matching are both empirically unimportant influences on immigrant earnings, and second, that they are important influences whose effects tend to cancel out.

In an attempt to distinguish between these alternative views, we examine higher-order moments in the distribution of residuals from the earnings equation. If the tails of the distribution are thinning as a result of outmigration and if the variance of earnings is increasing among Canadian immigrants who stay in Canada, we would expect increased kurtosis in the distribution of residuals for particular entry cohorts, i.e., the distributions should "thicken" from one census to the next. This pattern of results is clearly revealed in the last two columns of Table 10. However, because kurtosis also increases among native Canadians, a finding we had no reason to expect, we are reluctant to view our results for the immigrants as conclusive. It would thus appear that a fuller understanding of the dynamics of immigrants' labor market outcomes and their outmigration 
decisions awaits the advent of true, large-scale, longitudinal surveys of immigrants.

\section{Concluston}

This paper has reported estimates of simple wage equations fit to cross-sectional and pseudo-longitudinal data for Canadian immigrants in the 1971 and 1981 Canadian censuses. The estimates are used to assess (1) the usefulness of cross-sectional analyses for measuring the pace of immigrant earnings growth, (2) the labor market implications of admissions policies that place different weights on the work skills possessed by prospective entrants, and (3) the relative impact of selective outmigration and jobmatching on the shape of immigrant earnings distributions as duration of stay increases.

The estimates provide evidence of a small to moderate assimilation effect that suggests that immigrants make up for relatively low entry wages, although the wage catch-up is not complete until 13 to 22 years after entry into Canada. These results are revealed clearly in both the pseudolongitudinal and the cross-sectional analyses. The estimates also provide evidence that the unobserved quality of immigrants' labor market skills declined following changes in Canada's immigration policies in 1974 that led to a sharp increase in the proportion of immigrants admitted on the basis of family ties. Finally, since there is no evidence that the variance of immigrant earnings increases with their duration of stay in Canada, and since there are no differential immigrant-native changes in higher-order moments of the earnings distribution as duration of stay increases, the results are inconclusive with respect to the importance of selective outmigration and job matching in the evolution of immigrant earnings distributions over time. 
Table 1

Imnigration to Canada by Category of Admission Total Number of
Non-Refugee
Ymmigrants
839,045

456,143

909,882

785,079

593,862

468,731
Percent Admitted

as Sponsored or Assisted Relatives
Percent Admitted

from Independent Applications

(including refugees)

Sponsored Assisted

\section{Total Relatives Relatives}

$\begin{array}{llllll}1954-58 & 839,045 & 33.0 & \text { n.a. } & \text { n.a. } & 67.0 \\ 1960-64 & 456,143 & 44.6 & \text { n.a. } & \text { n.a. } & 55.4 \\ 1965-69 & 909,882 & 37.8 & \text { n.a. } & \text { n.a. } & 62.2 \\ 1970-74 & 785,079 & 49.3 & 24.7 & 24.6 & 50.7 \\ 1975-79 & 593,862 & 67.6 & 45.2 & 22.4 & 32.4 \\ 1980-84 & 468,731 & 64.2 & 54.2 & 10.0 & 35.8\end{array}$

n.a. not available

SOURCE: Employment and Immigration Canada, Annual Report to Parliament on Immigration Levels, selected years. 
Foreign-Born Members of the Canadian Population, Stocks and Flows

Total Canadian

$$
\text { Population }
$$

Year

(in mil1ions)
Percent

Foreign-born
1901

1911

1921

1931

1941

1951

1961

1971

1981
5.4

7.2

8.8

10.4

11.5

14.0

18.2

21.6

24.1
13.0

22.0

22.3

22.2

17.5

14.7

15.6

15.3

16.1

\section{Ratio of \\ Population Number of Immigrants Increase Immigrants to Population \\ Period (thousands) (thousands) Increase}

$\begin{array}{rrrrr} & 1901-11 & 1836 & 1759 & 0.96 \\ \text { F } & 1911-21 & 1581 & 1612 & 1.02 \\ \text { L } & 1921-31 & 1589 & 1203 & 0.76 \\ 0 & 1931-41 & 1130 & 150 & 0.13 \\ \text { W } & 1941-51 & 2502 & 548 & 0.22 \\ \text { S } & 1951-61 & 4229 & 1543 & 0.37 \\ & 1961-71 & 3330 & 1429 & 0.43 \\ & 1971-81 & 2515 & 1447 & 0.58\end{array}$

SOURCE: Author calculations based on data reported in Immigration Statistics 1983, Ottawa: Supply and Services, 1985. 
Table 3

Distribution of Intended 0ccupations Among Canadian Immigrants Planning to Work, by Year of Immigration (in percent)

\begin{tabular}{|c|c|c|c|c|c|c|}
\hline & \multicolumn{6}{|c|}{ Year of Immigration } \\
\hline Occupation & $\underline{1979-83}$ & $1974-78$ & $\underline{1969-73}$ & $1964-68$ & $1959-63$ & $1954-58$ \\
\hline Managerial & 6.3 & 7.5 & 5.1 & 2.4 & 2.1 & 1.4 \\
\hline Professional & 21.5 & 22.5 & 26.7 & 25.3 & 17.3 & 10.8 \\
\hline Clerical & 11.4 & 14.7 & 15.0 & 13.5 & 11.9 & 10.2 \\
\hline Service & 8.2 & 9.7 & 11.1 & 9.6 & 16.5 & 14.4 \\
\hline Agriculture & 4.1 & 2.2 & 3.1 & 3.2 & 7.5 & 9.2 \\
\hline Construction & 4.2 & 7.1 & 6.7 & 8.8 & 7.7 & 9.8 \\
\hline $\begin{array}{l}\text { Manufacturing } \\
\text { and Mechanical }\end{array}$ & 19.0 & 22.2 & 20.9 & 23.9 & 18.4 & 21.8 \\
\hline Laborers & 1.3 & 1.5 & 2.4 & 7.2 & 12.1 & 13.9 \\
\hline Other* & 24.0 & 12.6 & 9.0 & 6.1 & 6.5 & 8.5 \\
\hline Total & 100.0 & 100.0 & 100.0 & 100.0 & 100.0 & 100.0 \\
\hline
\end{tabular}

* "Other" includes Transportation and Communication, Commercial and Financial, Logging, Fishing, Trapping and Hunting, Mining and Quarrying, and Unspecified.

SOURCE: 1954-73: Employment and Immigration Canada, Annual Report to Parliament on Immigration Levels, 1980, p.14.

1974-83: Author calculations based on information reported in annual issues of Immigration statistics (Employment and Immigration Canada). 
Table 4

Canadian Immigrants by Country of Origin and Year of Immigration, 1981

Year of Immigration

\begin{tabular}{|c|c|c|c|c|c|c|c|c|}
\hline $\begin{array}{l}\text { Country of } \\
\text { Origin }\end{array}$ & $\begin{array}{l}1976 \\
1980 \\
\end{array}$ & $\begin{array}{l}1971 \\
1975 \\
\end{array}$ & $\begin{array}{l}1966 \\
1970 \\
\end{array}$ & $\begin{array}{l}1961 \\
1965 \\
\end{array}$ & $\begin{array}{l}1956 \\
1960 \\
\end{array}$ & $\begin{array}{l}1946 \\
1955 \\
\end{array}$ & $\begin{array}{l}\text { pre - } \\
\underline{1946} \\
\end{array}$ & Tota1 \\
\hline Africa & 233 & 390 & 255 & 106 & 39 & 16 & 14 & 1053 \\
\hline Asia & 1975 & 1720 & 889 & 245 & 209 & 201 & 75 & 5314 \\
\hline Belgium/Luxemburg & 20 & 12 & 25 & 10 & 55 & 72 & 34 & 228 \\
\hline Britain & 690 & 874 & 1209 & 646 & 1104 & 1833 & 2324 & 8680 \\
\hline France & 65 & 67 & 122 & 67 & 69 & 102 & 19 & 511 \\
\hline Germany & 73 & 92 & 213 & 176 & 473 & 764 & 84 & 1875 \\
\hline Greece & 36 & 139 & 229 & 169 & 176 & 84 & 18 & 851 \\
\hline Ireland & 20 & 26 & 29 & 12 & 31 & 19 & 23 & 160 \\
\hline Italy & 86 & 182 & 703 & 718 & 1068 & 1030 & 127 & 3914 \\
\hline Latin America & 793 & 1080 & 633 & 149 & 95 & 68 & 35 & 2853 \\
\hline Netherlands & 53 & 46 & 90 & 64 & 255 & 848 & 31 & 1387 \\
\hline Other Europe* & 399 & 778 & 999 & 456 & 869 & 848 & 718 & 5067 \\
\hline Other Non-Europe** & 89 & 113 & 95 & 31 & 25 & 29 & 12 & 394 \\
\hline Poland & 58 & 59 & 78 & 87 & 121 & 541 & 473 & 1417 \\
\hline Soviet Union & 80 & 34 & 28 & 21 & 49 & 614 & 476 & 1302 \\
\hline U.S. & 394 & 529 & 466 & 191 & 155 & 200 & 1007 & 2942 \\
\hline Total & 5064 & 6141 & 6063 & 3148 & 4793 & 7269 & 5470 & 37948 \\
\hline
\end{tabular}

* "Other Europe" includes Spain, Portugal, Scandinavia, and non-Soviet and Eastern Bloc countries.

** "Other Non-Europe" includes Australia, Pacific Islands, and other areas not otherwise 1 isted.

SOURCE: 1981 Canadian Census of Population, 1-in-100 sample. Data includes all immigrants (place of birth other than Canada) except inmates, members of the armed forces, and immigrants who arrived in 1981. 
Selected Labor Market Characteristics of Immigrants and Natives Aged 25-64 in 1981

Immigrants Natives

\begin{tabular}{|c|c|c|}
\hline $\begin{array}{l}\text { Labor Force Participation } \\
\text { Rate (ages } 15 \text { and over, } \\
\text { in percent) }\end{array}$ & 72.4 & 73.6 \\
\hline $\begin{array}{l}\text { Percent who worked } 49 \text { or } \\
\text { more weeks in } 1980\end{array}$ & 70.6 & 70.4 \\
\hline $\begin{array}{l}\text { Percent working } 35 \text { or } \\
\text { more hours during the } \\
\text { Census reference week }\end{array}$ & 93.3 & 91.9 \\
\hline Percent self-employed & 15.3 & 13.3 \\
\hline $\begin{array}{l}\text { Unemployment rate } \\
\text { (in percent) }\end{array}$ & 5.3 & 8.5 \\
\hline $\begin{array}{l}\text { Average wage and salary } \\
\text { income in } 1980 \text { among } \\
\text { those not primarily } \\
\text { self-employed (in } \\
\text { thousands of dollars) }\end{array}$ & 20.4 & 19.0 \\
\hline
\end{tabular}

SOURCE: Authors' tabulations of 1981 Census data. 


\section{Table 6}

Immigrant Labor Force Participation, Unemployment, and Income, by Year of Immigration, for Males in the 1971 and 1981 Censuses

Labor Force

Year of Participation Rate Unemployment Rate Immigration.

$\begin{array}{lcccccc} & 1981 & 1971 & 1981 & 1971 & 1980 & \underline{1970} \\ \text { Pre-1946 } & 29 & 47 & 4.4 & 4.6 & 23.4 & 18.8 \\ 1946-55 & 77 & 89 & 3.6 & 4.1 & 22.9 & 17.5 \\ 1956-60 & 84 & 86 & 3.9 & 5.0 & 21.1 & 17.0 \\ 1961-65 & 84 & 85 & 5.3 & 5.3 & 19.9 & 15.9 \\ 1966-70 & 82 & 81 & 6.1 & 6.1 & 21.1 & 14.8 \\ 1971-75 & 81 & \text { n.a. } & 6.7 & \text { n.a. } & 18.2 & \text { n.a. } \\ 1976-80 & 73 & \text { n.a. } & 8.0 & \text { n.a. } & 15.0 & \text { n.a. } \\ \text { Total } & 72 & 74 & 5.3 & 4.9 & 20.4 & 16.8\end{array}$

n.a. not applicable
Average Income (in thousands of

(in percent) current dollars)

$1981 \quad \underline{1971} \underline{1980} \quad \underline{1970}$

$\begin{array}{llll}4.4 & 4.6 & 23.4 & 18.8\end{array}$

$\begin{array}{llll}3.6 & 4.1 & 22.9 & 17.5\end{array}$

$5.0 \quad 21.1 \quad 17.0$ (in percent)

72
5.3

$4.9 \quad 20.4$

16.8 


\section{Table 7}

Variable Definitions and Descriptive Statistics for Male Immigrants and Natives in 1971 and 1981 [*]

Variables Definitions

YSM

$\mathrm{SCH}$

EXP

MST

IM7680

IM7175

IM6670

IM6165

IM5660

IM4655

Sample Size
Immigrants

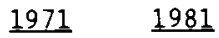

8.795

9.754

$(0.622) \quad(0.660)$ and salary income, nominal dollars

years since immigration

$15.121 \quad 18.383$

(8.884) (10.151)

education in years

$\begin{array}{ll}10.515 & 11.237 \\ (3.426) & (3.269)\end{array}$

$10.277 \quad 11.088$

(2.963)

(2.671)

$23.708 \quad 23.730$

$21.320 \quad 19.079$

work experience in years

(13.162) (12.371)

$(13.380)(12.806)$

$0.802 \quad 0.806$

0.762

0.725

(1-currently married)

imnigrated 1976-1980

. $\quad 0.104$

- $\quad 0.165$

$0.218 \cdot 0.189$

$0.111 \quad 0.103$

$0.187 \quad 0.164$

$0.338 \quad 0.230$

$8,290 \quad 9,368$ $\begin{array}{cc}8.710 & 9.667 \\ (0.691) & (0.689)\end{array}$

$\begin{array}{cc}8.710 & 9.667 \\ (0.691) & (0.689)\end{array}$

Notes for Tables $\underline{7-9}$

The immigrant samples represent 1 -in-100 samples of all immigrants in each Canadian census aged 20-64 who report working positive weeks and hours, who earned more than 50 cents per hour in the 1971 Census (one dollar per hour in the 1981 Census), and who are not primarily self-employed. Inmates, members of the armed forces, and immigrants arriving during the year in which the census was taken are excluded from the sample.

The native samples represent 1-in-600 samples of all natives in each Canadian census. The samples were constructed using the same criteria as those used to construct the immigrant sample, of those criteria that are relevant.

The regressions include vectors of categorical variables with information on hours worked per week and weeks worked per year. 


\section{Estimated Wage Equations for Immigrants and Natives}

Using Single Cross-Sections: Hales [*]

\begin{tabular}{|c|c|c|c|c|c|c|}
\hline \multirow[t]{2}{*}{ Varlable } & \multicolumn{2}{|c|}{ Immigrants } & \multicolumn{2}{|c|}{ Nat1ves } & \multirow{2}{*}{$\frac{\text { Imm1 gIants }}{1971}$} & \multirow{2}{*}{ and Natives } \\
\hline & 1971 & 1981 & 1971 & 1981 & & \\
\hline \multirow[t]{2}{*}{ YSH(XIMHIG) } & .0044 & .0053 & -- & -- & .0054 & .0077 \\
\hline & $(.0007)$ & $(.0006)$ & & & $(.0006)$ & $(.0005)$ \\
\hline \multirow[t]{2}{*}{ SCB } & .0427 & .0447 & .0670 & .0574 & .0528 & .0486 \\
\hline & $(.0022)$ & $(.0018)$ & $(.0025)$ & $(.0025)$ & $(.0014)$ & $(.0014)$ \\
\hline \multirow[t]{2}{*}{ EXP } & .0376 & .0400 & .0405 & .0436 & .0385 & .0421 \\
\hline & $(.0016)$ & $(.0017)$ & $(.0021)$ & $(.0019)$ & $(.0013)$ & $(.0013)$ \\
\hline \multirow[t]{2}{*}{$\operatorname{EXPSQ}(-100)$} & -.0681 & -.0692 & -.0655 & -.0701 & -.0658 & -.0705 \\
\hline & $(.0030)$ & $(.0033)$ & $(.0042)$ & $(.0039)$ & $(.0024)$ & $(.0025)$ \\
\hline \multirow[t]{2}{*}{ MST } & .1569 & .1820 & .1963 & .1920 & .1754 & .1875 \\
\hline & $(.0137)$ & $(.0132)$ & $(.0169)$ & $(.0147)$ & $(.0107)$ & $(.0099)$ \\
\hline \multirow[t]{2}{*}{ IMMIG } & -- & -- & -- & -- & -.0693 & -.1657 \\
\hline & & & & & $(.0123)$ & $(.0120)$ \\
\hline \multirow[t]{2}{*}{ Constant } & 6.6074 & 6.6777 & 6.1279 & 6.5665 & 6.3749 & 6.6566 \\
\hline & $(.0751)$ & $(.0683)$ & $(.0676)$ & $(.0613)$ & $(.0444)$ & $(.0399)$ \\
\hline $\mathrm{R}^{2}$ & .485 & .509 & .554 & .543 & .508 & .516 \\
\hline RSS & 1651.0 & 2004.9 & 1089.9 & 1364.6 & 2790.5 & 3433.9 \\
\hline $\mathbf{N}$ & 8290 & 9368 & 5119 & 6295 & 13409 & 15663 \\
\hline
\end{tabular}

* See Notes at bottom of Table 7

Estimated standard errors are reported in parentheses below the coefficient estimates. 
Tablo 9

Wage Equations for Male Immigrants In Canada Based on Pooled 1971 and 1981 Data

$\begin{array}{cccc} & \text { Within-Cohorts Model } & \text { Within-Cohorts Model } \\ \text { Cross-Cohorts } & \text { Within-Cohorts } & \text { Using Samp Average } & \text { Using Weightod Average } \\ \text { Model } & \text { Model } & \text { Productivity Adjustment } & \text { Productivity Adjustment }\end{array}$

YSM

$.0076 \quad .0202$

.0024

(.0008)

.0437

(.0013)

$(.0013)$

$(.0013)$

EXP

$$
.0401
$$

(.0012)

.0383

(.0012)

EXPSQ (-100)

$$
-.0719
$$$$
\text { (.0022) }
$$

$-.0675$

$(.0022)$

$$
.1711
$$

(.0096)

CONSTANT

$$
6.6467
$$$$
\text { (.0508) }
$$

IM7680

IM7 175

IM6570

IM6165

IM 5660

IM4655

$$
\mathrm{R}^{2}
$$

RSS

N
.4713

$$
\text { (.0302) }
$$

$$
.5062
$$

$$
\text { (.0261) }
$$

.4548

$$
(.0241)
$$

$$
.3684
$$$$
(.0224)
$$

$$
.2730
$$

$$
(.0289)
$$

$$
\begin{array}{r}
.1675 \\
(.0155)
\end{array}
$$

.00494

$$
37.663
$$

.00506

$$
36.757
$$

17658

$$
.0383
$$$$
\text { (.0012) }
$$

$-.0675$

$(.0022)$

$$
.1723
$$$$
\text { (.0095) }
$$

\subsection{0}

(.0564)

$-.1874$

$(.0302)$

$-.0634$

(.0261)

$-.0259$

(.0241)

$-.0233$

(.0224)

$-.0296$

(.0289)

$-.0104$

(.0155)

.00496

36.757

17658

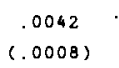

6. 8828

(.0563)

$-.1163$

(.0302)

$-.0066$

(.0260)

.0142

$(.0240)$

.0216

(.0223)

$-.0034$

(.0188)

$-.0025$

(.0154)

.00501

36.612

17658

* See Notes at bottom of Table 7

Estimated standard errors are reported in parentheses bolow coeffictent estimates. 
Dispersion and Kurtosis in Conditional and Unconditional Distributions of Wage and Salary Income, for Male Immigrants, by Census Year [*]

\begin{tabular}{|c|c|c|c|c|c|c|}
\hline \multirow[t]{2}{*}{$\begin{array}{l}\text { Sample/ } \\
\text { Entry Cohort }\end{array}$} & \multicolumn{2}{|c|}{$\begin{array}{l}\text { Std. Dev. of } \\
\text { Immigrant } \\
\text { Earnings } \\
\text { (000 dollars) }\end{array}$} & \multicolumn{2}{|c|}{$\begin{array}{l}\text { Std. Dev. of } \\
\text { Residuals in } \\
\text { Log Earnings } \\
\text { Equation }\end{array}$} & \multicolumn{2}{|c|}{$\begin{array}{l}\text { Kurtosis of } \\
\text { Residuals in } \\
\text { Log Earnings } \\
\text { Equation }\end{array}$} \\
\hline & 1971 & 1981 & 1971 & 1981 & 1971 & 1981 \\
\hline $\begin{array}{l}\text { A11 pre }-1970 \\
\text { immigrants }\end{array}$ & 12.2 & 11.0 & 0.45 & 0.44 & 2.9 & 3.7 \\
\hline $\begin{array}{l}\text { Native } \\
\quad \text { Canadians }\end{array}$ & 11.8 & 10.9 & 0.46 & 0.47 & 2.3 & 2.8 \\
\hline Pre-1946 & 15.7 & 12.2 & 0.48 & 0.46 & 3.0 & 2.4 \\
\hline $1946-55$ & 11.3 & 10.8 & 0.42 & 0.42 & 3.6 & 4.6 \\
\hline $1956-60$ & 11.0 & 10.4 & 0.41 & 0.44 & 2.5 & 5.0 \\
\hline $1961-65$ & 10.3 & 11.4 & 0.44 & 0.46 & 2.6 & 3.5 \\
\hline $1966-70$ & 12.6 & 10.9 & 0.55 & 0.47 & 2.1 & 3.3 \\
\hline
\end{tabular}

[*] The equation used to estimate the residuals and to calculate their standard deviation and kurtosis is reported in column 3 of Table 9 . 
Allen, J. 1979. "Information and Subsequent Migration: Further Analysis and Additional Evidence." Southern Economic Journal 45: 1274-1284.

Blejer, M. and I. Goldberg. 1980. "Return Migration - Expectation Versus Reality: A Case Study of Western Migrants to Israel." In Simon, J. and J. DaVanzo, Eds., Research in Population Economics 2: JAI Press.

Borjas, George. 1982. "The Earnings of Male Hispanic Immigrants in the United States." Industrial and Labor Relations Review. 35: 343-353.

. 1985. "Assimilation, Changes in Cohort Quality, and the Earnings of Immigrants." Journal of Labor Economics. 3: 463-489.

Carliner, Geoffrey. 1980. "Wages, Earnings, and Hours of First, Second, and Third Generation American Males." Economic Inquiry. 18: 87-102.

Chiswick, Barry. 1978. "The Effect of Americanization on the Earnings of Foreign-Born Men." Journal of Political Economy. 86: 897-921.

Fox, Marc. 1987. "Remittance and Labor Supply Behavior of Immigrants." Unpublished Ph.D. dissertation, Department of Economics, Harvard University. Green, Alan G. 1976. Immigration and the Postwar Canadian Economy. Macmillan of Canada.

Harris, Milton and Bengt Holmstrom. 1982. "A Theory of Wage Dynamics." Review of Economic Studies. 315-333.

Jasso, Guillermina and Mark R. Rosenzweig. 1987. "How Well Do Immigrants Do? Vintage Effects, Emigration Selectivity, and the Occupational Mobility of Immigrants." Research in Population Economics. JAI Press.

Jasso, Guillermina and Mark R. Rosenzweig. 1989. "Self-Selection and the Earnings of Immigrants: Comment." American Economic Review. Forthcoming.

Katz, Eliakim and Oded Stark. 1984. "Migration and Asymetric Information: Comment." American Economic Review: 533-534.

Lam, Kitchun. 1986. "Imperfect Information, Specificity of Schooling and Rate of Return-Migration." Economics Letters 21: 283-289.

Lam, Kitchun. 1987. "An Analysis of the Outmigration of Foreign-Born Members in a Population." Unpublished Ph.D. thesis, Harvard University Department of Economics.

Long, James E. 1980. "The Effect of Americanization on Earnings: Some Evidence for Women." Journal of Political Economy. 88: 620-629.

Stark, Oded and David E. Bloom. 1986. "The New Economics of Labor Migration." American Economic Association Papers and Proceedings 75: 173 178 .

Yezer, Anthony and L. Thurston. 1976. "Migration Patterns and Income Changes: Implications for the Human Capital Approach to Migration." Southern Economic Journal 42: 693-702. 